Original Research Paper

\title{
Taxation of End Consumption: Effect on Country Economies and its Characteristics
}

\author{
${ }^{1}$ Ravil Gabdullaevich Akhmadeev, ${ }^{2}$ Mikhail Evgenievich Kosov, \\ ${ }^{3}$ Olga Alekseevna Bykanova, ${ }^{4}$ Svetlana Viktorovna Frumina and ${ }^{5}$ Marina Vladimirovna Melnichuk \\ ${ }^{I}$ Department of Accounting and Taxation, Plekhanov Russian University of Economics, Moscow, Russia \\ ${ }^{2}$ Department of Finance and Prices, Plekhanov Russian University of Economics, Moscow, Russia \\ ${ }^{3}$ Department of Mathematics, Plekhanov Russian University of Economics, Moscow, Russia \\ ${ }^{4}$ Deputy Head of Department Theory of Finance, \\ Financial University Under the Government of the Russian Federation, Moscow, Russia \\ ${ }^{5}$ Head of the Department of Foreign Languages-3, \\ Financial University Under the Government of the Russian Federation, Moscow, Russia
}

Article history

Received: 31-05-2016

Revised: 19-01-2017

Accepted: 20-01-2017

Corresponding Author:

Ravil Gabdullaevich

Akhmadeev

Department of Accounting and

Taxation, Plekhanov Russian

University of Economics,

Moscow, Russia

Email:ahm_rav@mail.ru

\begin{abstract}
International experience of the largest countries' economies of the last decade demonstrates that the use of Value Added Tax (VAT) in taxation of consumption is used more actively and is gradually squeezing out the sales tax. In most countries of the world VAT ensures between 12 and $30 \%$ of stable budget revenues. Taking statistical data selected with the help of the Ordinary Least Squares method as a basis, changes in the ratio of VAT received by the budget to GDP in the economies of different states for the $1995-2015$ period were studied. The best ratio of the economic data was revealed in the Czech Republic and Mexico, where sustainable growth of the ratio amounted to $0.0008-0.0009$ respectively. A significantly lower correlation of the data was noticed in Austria and France, the correlation is conspicuous for its negative value of the regression coefficient. The research we have undertaken in relation with several states has shown the following consistent pattern: an average value of the share of VAT is less (by 10\%) dependent on the development and state of the economy of the countries we have compared than (over $60 \%$ ) on the taxation rules established by laws on each state (the use of tax incentives, lower tax rates, etc.). Our research of VAT effect on the economies of countries has revealed a number of specific problems, which weaken the mechanism of collection and payment of the tax. Consequently, to solve the macroeconomic problems of VAT, additional measures aimed at organizations' revenue growth should be undertaken. Another area should be the improvement of the tax incentive and exemption system as well as the removal of existing possibilities of tax evasion. These measures will allow the government to adjust the basic rate downwards in the middle term.
\end{abstract}

Keywords: Taxation of Added Value, State Budget, Tax Incentives and Breaks, Ordinary Least Squares Method, Regression Analysis, Tax Administration

\section{Introduction}

Looking back into the history of the tax, VAT failed at the start of the $\mathrm{XX}^{\text {th }}$ century, because the society was not ready for the introduction of a tax collected at all stages of production and covered a significant part of sales operations of goods (works, services). For example, in the $30 \mathrm{sec}$ of the $\mathrm{XX}^{\text {th }}$ century a research by Gerhard
Colm "The Ideal Tax System" was the first to say that VAT corresponds to the current stage of capitalism development, because the state has turned into a partner, which ensures production process, from a guarantor of ownership (Couzin, 2014). According to Joseph J. Thorndike, the government ensures private production by laying roads among other things, the state raises the efficiency of entrepreneurship through education and 
support of technological research, while commercial risks are diminished thanks to public interference during crises. The state increases and supports incomes of business. A prototype of VAT was put forward in several countries of the world at the same time. Thus, a new tax suggested by Wilhelm von Siemens in Germany in 1919 was called "a refined turnover tax". In 1921, American economist Thomas S. Adams proposed value added tax as a replacement for a corporate tax in the USA. None of the proposals were accepted. Nevertheless, the ideas were debated from time to time (Amand, 2007).

As Alan Schenk and Oliver Oldman said in their work "Value added tax: A comparative approach" (Schenk and Oldman, 2007), the introduction of VAT required a critical volume of practical problems and experience. The universal taxable item (goods, works and services) resulted from a long evolution from single stage consumption taxes (excises) to turnover taxes. In practically all the states, which introduced VAT, it was preceded by multi-stage turnover taxes, more progressive compared with excises, but not without many and significant drawbacks (Adams, 1918).

For instance, a purchase tax, introduced in 1940, was VAT predecessor in Great Britain. The tax was calculated by wholesalers and was shifted to the end consumer. The object of the tax included a wide range of goods services excluded (Chernik, 2015).

Financier and employee of the finance ministry Maurice Lauré was the author of French VAT. France has begun experimenting with tax rebates and deductions with the aim of removing the cascade effect since the end of $40 \mathrm{sec}$. It was only in 1954 that a system corresponding to the current VAT order appeared - the tax was calculated when goods were sold, while the tax paid to the supplier was deducted from the taxation base. The new economic invention had been tested in the French colony of Cote-d'Ivoire for ten years and was only introduced in the metropolis at the end of the $60 \mathrm{sec}$.

We should single out two key factors, which initiated we should single out two key factors, which initiated active movements towards VAT introduction. Firstly, the countries-participants of the Rome agreement had cascading general sales taxes at the moment of its signing in 1957. It resulted in a lot of inconveniences, primarily due to obligations undertaken by the states in the framework of the agreement and consequently, in the period of $1960-1970$ the aforementioned states replaced the sales tax with VAT. Secondly, the governments of Scandinavian countries regarded VAT as a potential source of additional budget revenue as compared with single stage taxes on wholesale (in Denmark) or retail sales (in Norway or Sweden) when planning a gradual growth of state social spending. Together with the modern lack of wish to increase state budget revenue via higher tax rates on households' incomes, it resulted in these states transition to a multistage taxation of added value in the period of 1967 - 1970 (Black, 2012).

At present, there is a single added value taxation system in the framework of the European community, which is based on the following:

a) The EC states levy the tax on the same goods and services

b) A single order of tax calculation is used

c) Approximately the same rates are used

The problems linked with the improvement of indirect taxation, including value added tax, are currently rather pressing in the Russian Federation as well. Thus, there have been constant discussions regarding the expediency of levying VAT, the rates and the order of calculation of the tax liability, the volume and structure of reliefs, the order of levying the tax on exports and imports of goods and services since 1992. When VAT was introduced in Russia in 1992, it amounted to $28 \%$. It was later cut to $20 \%$, while since 2004 and until now the key rate of the tax amounts to $18 \%$. A preferential rate of 0 and $10 \%$ was not changed. We should note that VAT in the OECD countries holds a leading position in the group of taxes on general consumption. It amounts to $6.6 \%$ of GDP on average and stands at $19.5 \%$ of the overall tax collection. The order of collecting value added tax in international taxation saw growing demand in the last 50 years. At the end of the $60 \mathrm{sec}$ of the $\mathrm{XX}^{\text {th }}$ century, the tax was levied in only ten countries, while the number of the countries reached 160 by 2014 (Fig. 1). We should note that VAT in developed countries is characterized as one of the key budget-making taxes, ensuring a significant amount of tax receipts of the budgets (Fig. 2).

We have undertaken an analysis of changes in the share of budget receipts of VAT as a ratio to GDP taking statistical data selected with the help of the OLS method as a basis taking such states as the Czech Republic, France, the Federative Republic of Germany, the United Mexican States, the Republic of Austria, the Kingdom of Spain, the United Kingdom, the Swiss Confederation as an example. We have used regression analysis (in the period of 1995 - 2015) to compile trend equations, which characterize the growth/fall function of the tax collection in the countries of our research. As a result, the best ratio was revealed in Mexico and the Czech Republic, because their ratio correlation of $y=0.0008 x$ $+0.0247, \mathrm{R}^{2}=0.818$ (for Mexico) and $\mathrm{y}=0.0009 \mathrm{x}+$ $0.0543, \mathrm{R}^{2}=0.782$ (for Czech Republic) means sustainable growth of the ratio of VAT receipts by the budget to GDP volume at 0.0008 to 0.0009 reciprocally (equations of time series, where $\mathrm{x}$ is time). However, a significant decrease of VAT collection to the volume of GDP was also noted in France and Austria, the connection is characterized by a regression coefficient of -0.0002 . 


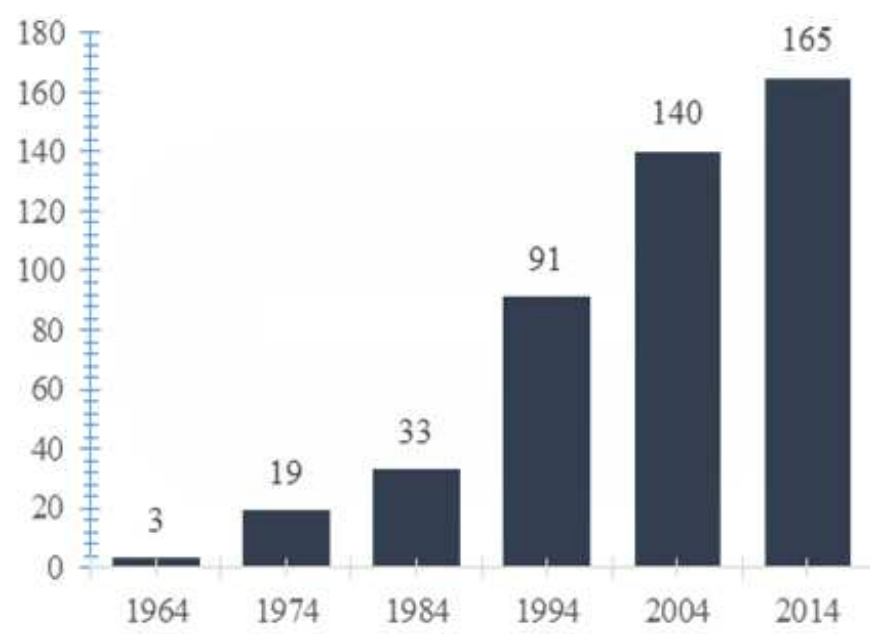

Fig. 1. The number of countries, which use VAT on their territories (Source: Compiled with the help of data from http://www.oecdilibrary.org/taxation/consumption-tax-trends-2014_ctt-2014-en)

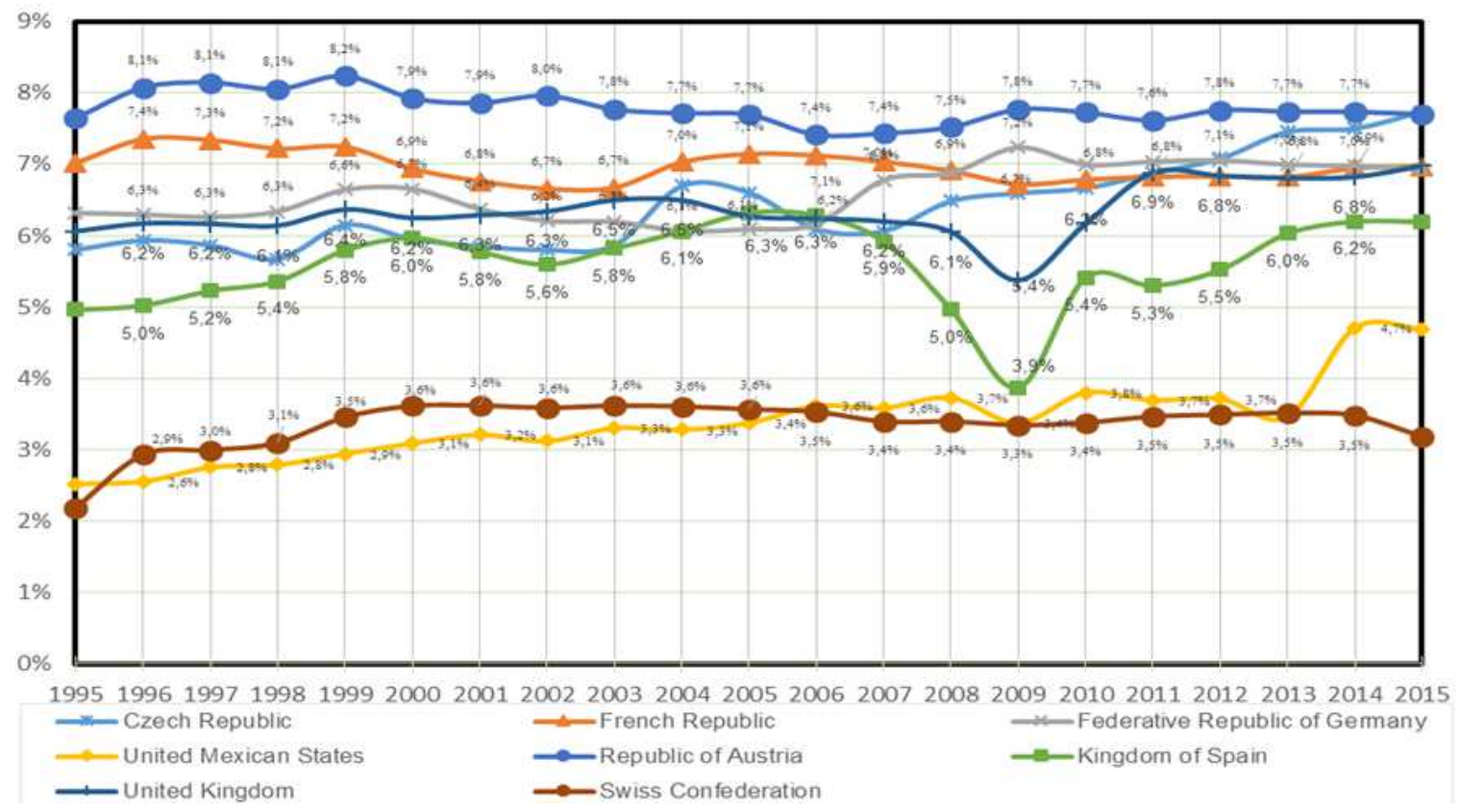

Fig. 2. VAT as percentage of GDP in some countries, $\%$

We should note that in conditions of an international economic crisis of 2008-2009, some countries, the United Kingdom, the Kingdom of Spain, the United Mexican States demonstrated a significant decrease in the value of the share of VAT receipts to the volume of GDP. At the same time, significant growth of this figure is noted in these countries in $2010-2015$. This is demonstrated by positive coefficients of $0.0003,0.0002$, 0.0008 in the countries under analysis respectively, which shows a derivative of the trend function and consequently, the speed of its change. At the same time in the Republic of Austria, despite smoother effects of the international economic crisis there is a tendency towards a fall in the figure in question, which is confirmed by the value of the coefficient of -0.0002 of the trend line.

At the same time, the role of VAT in the international at the same time, the role of VAT in the international economy is ambiguous. In particular, economies believe that the tax ensures budget needs in the best possible way. On the other hand, analysts criticize the tax for being excessively fiscal as well as for the complicated order of defining the taxation object and high rates. In their view, emerging economies have difficulties in using 
VAT, there are objective reasons of the calculation methodology and tax payments. Nevertheless, one should take into account a serious argument - the tax is used in more than 160 states of the world. We should note that experts are of a different view regarding the necessity of VAT cancellation and introduction of a sales tax. The key arguments in favour of VAT are the following:

a) When a country introduces VAT, control over the sums of budget receipts and the efficiency of production of goods (work, services) becomes much better than with the sales tax. The price for the end consumer is affected less compared with single stage or cascade sales taxes (Crum, 1982)

b) A wider taxation base of VAT (Moles, 1997) because not only retail sales are taxed, but also all nonproduction acquisitions of organizations, whose tax payers are end consumers, including works performed by the company itself for its own needs

c) A mass transfer to the use of VAT in a period when state spending grows significantly to satisfy increasing social needs of the society. In this case either a serious increase of the income tax is necessary, or a search for new sources of budget revenue

d) The mechanism of VAT collection ensures VAT receipt at all production stages ensuring sustainable budget receipt volumes regardless of fluctuations in the trend of the retail business, external shocks and the behavior of any category of a tax payer (the problem of tax evasion)

\section{Concept Headings}

VAT, which is an indirect tax, is a tax on end consumption and is paid at each stage of production and distribution, meaning that each producer or distributor pays it when selling goods (works, services). The international practice of levying and paying taxes shows that VAT does not distort the production process and does not affect the choice of a legal organizational form by a company. Another quality of the tax is the neutrality principle for investment, which, in its turn, promotes its wider use not only in developed, but also in emerging countries. In particular, only the USA out of 34 OECD states uses another indirect tax, a Retail Sales Tax (RST). Most emerging economies introduced VAT on their territories due to trade liberalization and higher tax receipts by the budgets in the last several decades. We should outline the key principles inherent in the tax:

a) The principle of end consumption. The basis of the mechanism of VAT collection is the function of consumption by households (end users), who, unlike companies, participate in consumption. The international taxation practice formulates the following clause: "Companies acquire and use capital investment, goods, materials, etc., but they do not consume them in the direct meaning of the word," i.e., VAT is by definition a tax on transactions

b) The principle of multistage construction. The tax is levied at each stage of production and distribution from added value received. At that, each participant of the business process takes part in the mechanism of forming tax liabilities. This is why VAT for companies taxes the value of the results of their operation, while there is the right for a tax rebate on the price of the purchase or compensation from the tax authorities for their counteragents. This is a key difference in the order of VAT calculation compared with the retail sales tax, which is a single stage tax and is only levied on the end sales of goods (works, services)

International practice of VAT collection applies two main approaches, which ensure timely control over the correctness of the taxation base calculation simultaneously.

The credit or invoice (transaction based) method is used via presentation of invoices at each delivery to the buyer with the mentioning of the tax volume. The size of the tax $T_{V A T}$ to be paid to the budget is calculated from the added value (the tax liability less tax credit (deduction)) according to the formula:

$T_{V A T}=$ Svat $x(P \times Q)-$ Svat $x M$

Where:

Svat $=$ Added value

$\operatorname{PxQ}=$ The size of delivery (contracted price), monetary unit

$M \quad=$ The size of material costs linked with production (purchase), monetary unit

The order of payments is defined at the moment the tax liability appears with the seller-VAT payer in accordance with the rule of the first event: either at the date of the shipment of goods (works, services), or at the date of the means of payment arrival. By the same token, the right of the buyer for a tax credit is defined by the date of an earlier event. A tax credit includes VAT, calculated or paid to the suppliers at the moment of the purchase of material values (works, services) necessary for entrepreneurial activities. If the balance is positive, VAT is paid to the budget, or the right for the tax repayment is provided (if the balance is negative). The use of the method in conditions of economic instability triggers multiple problems at the micro level linked with a growing tax burden, leads to erosion of working assets and hurts the financial state of enterprises. Most countries use the invoice method of VAT collection as a universal means of control, which prevents tax evasion (Fig. 3). 


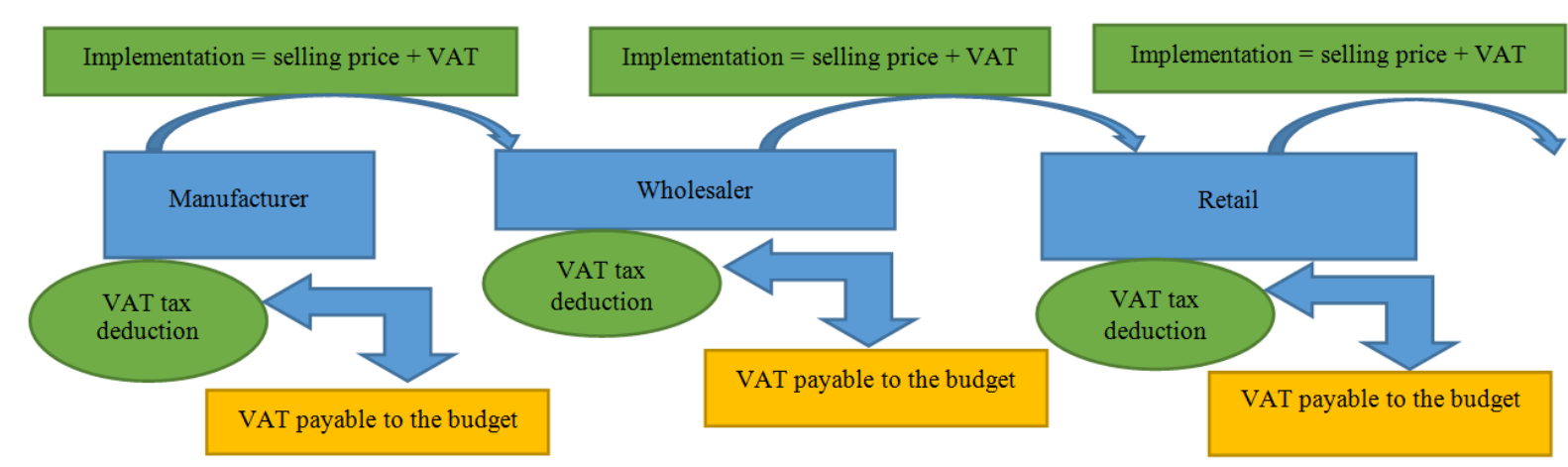

Fig. 3. The mechanism of VAT collection and payment when selling goods (works, services)

\section{Statistical Methodology}

The function of taxation neutrality is typical of VAT. This feature of the tax is used to tax trade operations on the international market. In particular, the Russian order of VAT collection offers exporters this possibility using tax exemption of a $0 \%$ rate. In their turn, organizations have the right to use tax deductions on the goods (works, services) (Fig. 4). We should note a significant amount of empiric data for the period of 2005-2015. This is why the method of OLS was used. The resulting equation of a trend line $\mathrm{y}=0.0002 \mathrm{x}+0.2945, \mathrm{R}^{2}=0.4$ (relative to time), characterizes growth of the share of VAT tax deductions in the total Russian export for the period under consideration, which is characterized by a positive coefficient of 0.0002 .

In their turn, imported goods are taxed with the same VAT as the goods (works, services) produced in the country. Compared with the mechanisms of tax deductions in EC states, VAT must be paid into the budget in Russia. This form of economic "neutrality" is important for the correct functioning of the international trade mechanism (Fig. 5).

The OLS method is used to generate the function, which describes the trend of VAT deduction changes compared with the volume of Russian imports allowed us to receive an equation of a trend line of $\mathrm{y}=0.0293 \mathrm{x}^{0.22}$ (power function, non-dimensional time). A derivative of this function calculated at positive variables of more than 0 , which demonstrates growth in the share of VAT tax deductions in the share of Russian imports growth.

We should note that VAT has a direct effect on the economy. In particular, the higher the share of material costs, performed works or rendered services of other organizations in the total cost of produced goods, the smaller part of its turnover will be taxed. Labour-intensive branches of the economy with a high share of net product in the gross turnover are in unfavourable economic conditions.

The psychological feature of added value tax is that its high share in revenue is unnoticeable, because goods consumers pay VAT, which is already included into the price. This fact helps avoid a conflict with the consumers of goods, works, services (taxpayers) and diminishes social resentment when the rate of the tax is increased or decreased (Akhmadeev et al., 2016).

At that, the regressively of the tax is its negative fact: financially disadvantaged citizens feel the large burden, which the tax creates for their incomes (Law and Owen, 2010; Law, 2009). Consumers buy the same goods at the same set prices, which include a fixed size of value added tax regardless of the size of their incomes. In this case, financially disadvantaged citizens spend most of their incomes to pay value added tax.

Apart from the fiscal function, which is manifested in a stable inflow of financial resources into the budget so that the state could function, indirect taxes have a more important role of regulation. The processes of price formation and consumption are affected through the system of rate setting. The larger part of international countries use standard rules of the mechanism of calculation and payment of value added tax (Fig. 6).

The statistical analysis we have undertaken for several countries has allowed us to formulate the following. An average value of the VAT share in budget revenues is less $(10 \%)$ dependent on the development and state of the economies of the countries under comparison. The values are much more dependent on the taxation rules set by legislation of each state: the use of tax reliefs, lower tax rates, etc. Let's research the connection between the GDP growth rates and the volumes of VAT collections taking the Russian economy as an example (Table 1).

On the basis of the correlation analysis of the data we received in 2007-2015 we have formulated the following: the connection between GDP growth rates and the amount of VAT collections in Russia is of medium strength and opposite, which is characterized by a negative correlation coefficient of -0.33 . We should stress that when taken at paired regression the determination coefficient equals a squared correlation coefficient (Table 2 ). In its turn, the coefficient of determination amounts to $\mathrm{R} 2=0.11(0.11<<1)$, which confirms the weak influence of qualitative values of GDP on the amount of VAT budget collections. It is important that we single out the important influence of other factors affecting taxation in a country. In particular, the imperfection of tax legislation for some categories of tax payers. 


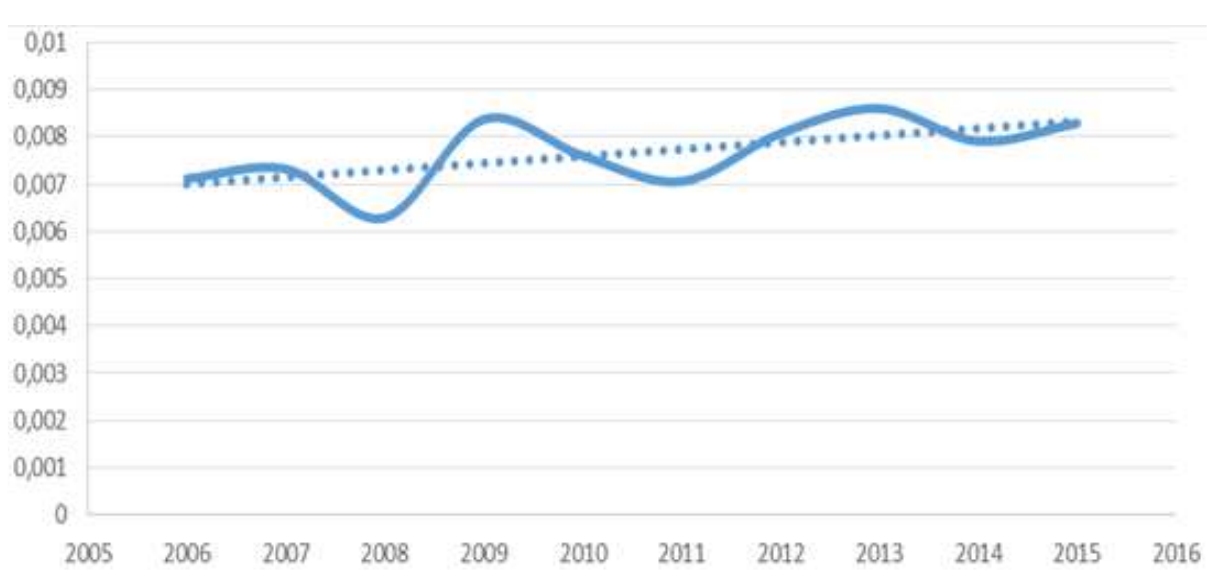

Fig. 4. A research of a ratio of VAT deductions to Russian exports (mln U.S. dollars/ mln U.S. dollars)

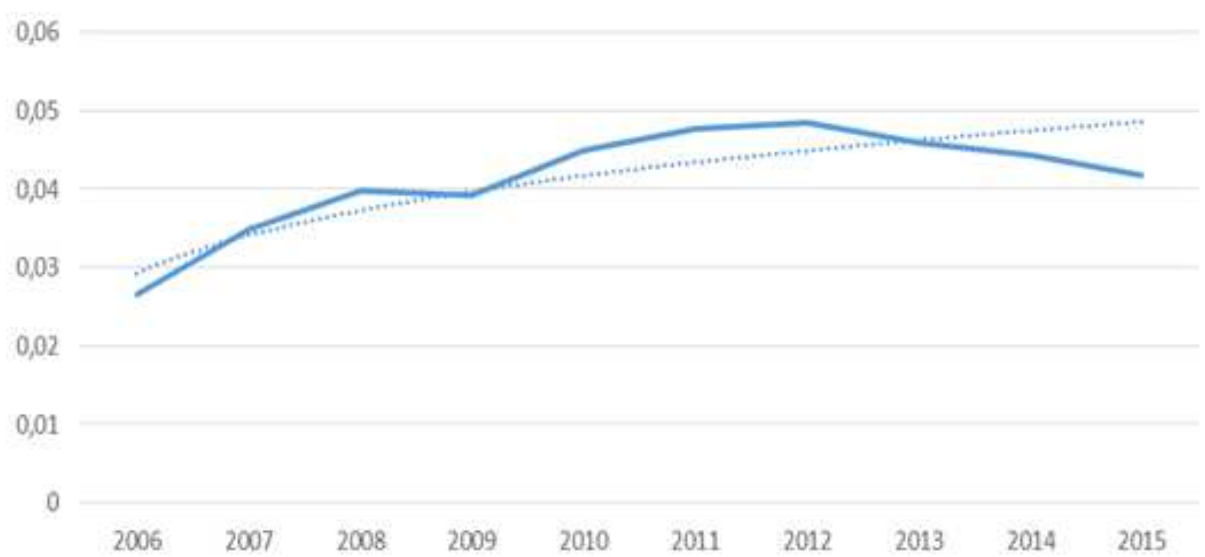

Fig. 5. A research of a ratio of VAT deductions to Russian imports (mln U.S. dollars/ mln U.S. dollars)

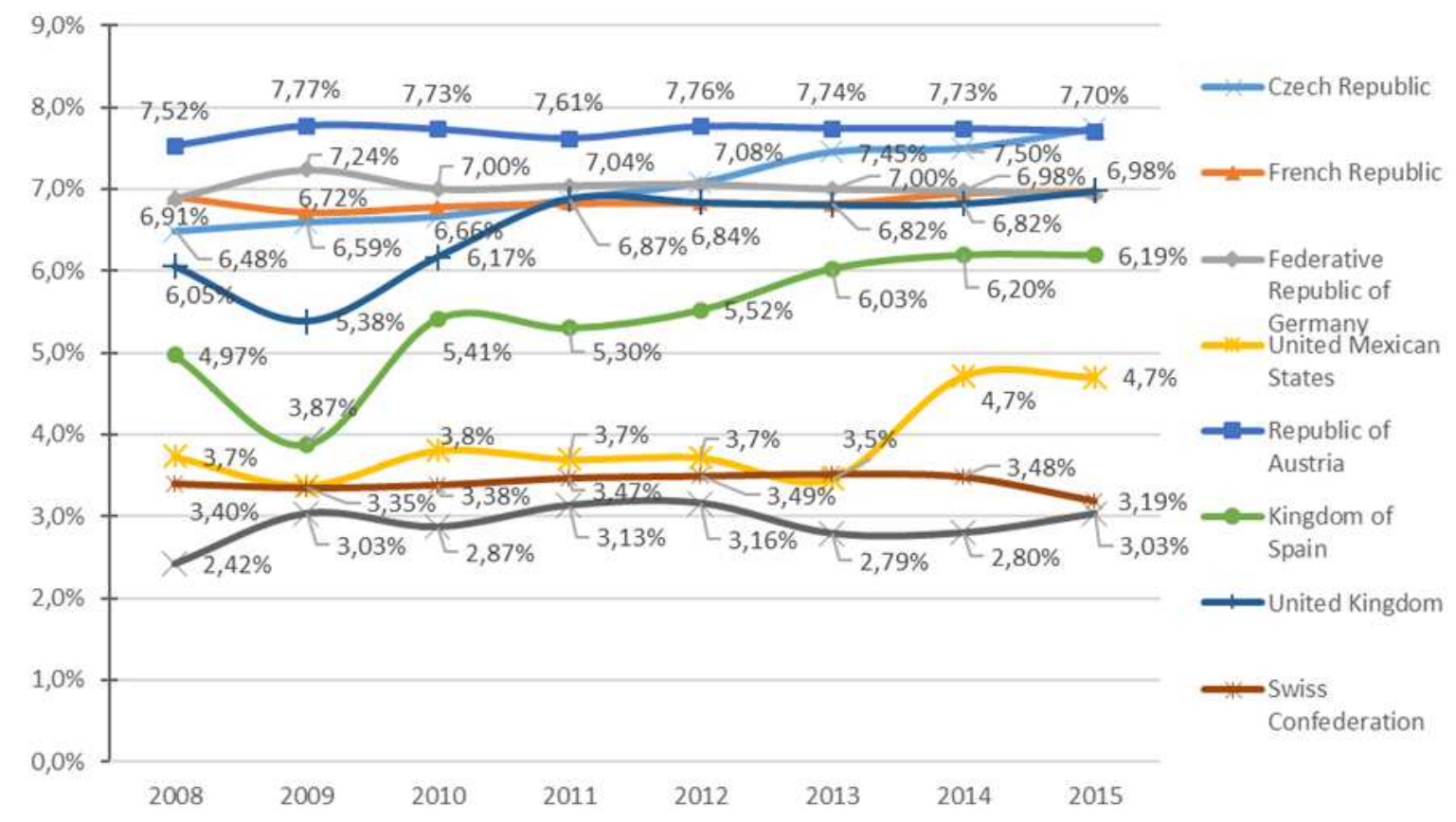

Fig. 6. The share of revenues from VAT to the budget income countries, $\%$ 


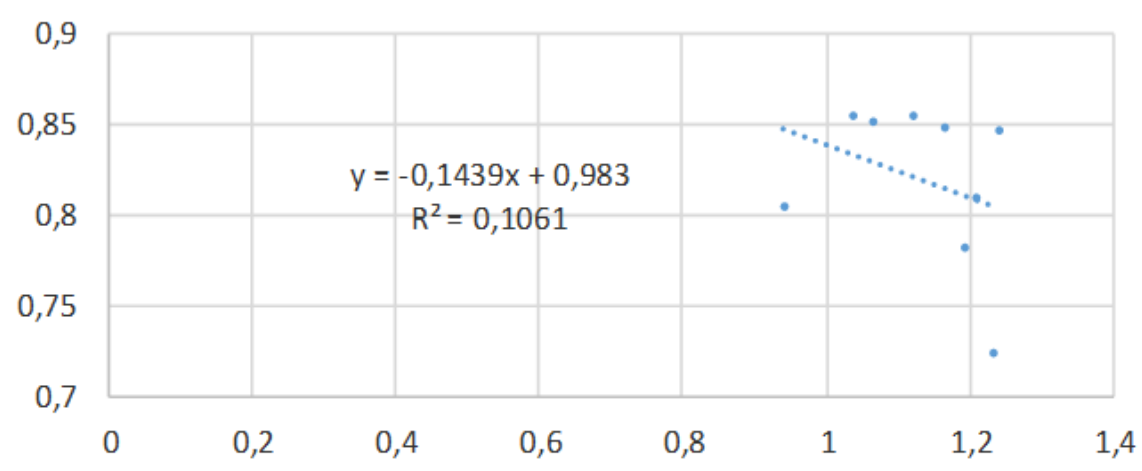

Fig. 7. Dependence of VAT collection in the Russian budget on the GDP growth rate

Table 1. A research on the interconnection between GDP growth rates and the amount of VAT collections in Russia in the period of 2007-2015

\begin{tabular}{lll}
\hline & Rate of a gain of GDP (\%) & The VAT share (\%) \\
\hline 2007 & 1.235177000 & 0.722867000 \\
2008 & 1.241501850 & 0.847789712 \\
2009 & 0.901691100 & 0.804337632 \\
2010 & 1.193297095 & 0.782459516 \\
2011 & 1.208572443 & 0.809232080 \\
2012 & 1.066666206 & 0.851818519 \\
2013 & 1.121088341 & 0.855070294 \\
2014 & 1.164630578 & 0.848519551 \\
2015 & 1.036682738 & 0.855651402 \\
\hline
\end{tabular}

Table 2. Calculation of the correlation coefficient

\begin{tabular}{lll}
\hline & Column 1 & Column 2 \\
\hline Column 1 & 1.00000 & - \\
Column 2 & -0.32579 & 1.00000 \\
\hline
\end{tabular}

The OLS method used when analyzing the data confirms the results we have received by the following equation $\mathrm{y}=0.983-0.14 \mathrm{x}$, where $\mathrm{y}-$ is the level of VAT collections for the budget (the share), $\mathrm{x}$ - is GDP growth rates in the corresponding periods of time. The negative regression coefficient of -0.14 characterizes opposite vectors of changes of the values making part of the equation (Fig. 7).

\section{Discussion}

Improvements in the mechanism of calculation and payment of value added tax is constantly discussed at different international economic forums, where other methods to augment measures to simplify the general taxation order, to cut the key rate of the tax are suggested. We are talking about replacing it with another indirect tax, with the retail sales tax. At that, Russia introduced the retail tax in 1998 as a regional tax and it was valid for six years together with VAT. At that, if the tax was introduced by the territories, collection of a range of other local taxes and levies ceased and there was also a clear list of goods and services exempt from taxation (Kosov and Akhmadeev, 2015). But after the sales tax was cancelled in 2004 retail prices for goods and services did not go down. When replacing VAT with a sales tax one should keep in mind the following circumstances. There is no doubt that there will be a socalled cascade effect when a sales tax is introduced, because it is linked with the fact that tax payers will pay the tax anew when spare parts, materials are resold. Besides, according to experts, the rate of the sales tax should be $30 \%$ or more to replace value added tax (Akhmadeev and Kosov, 2015). At that, when a sales tax is introduced, its rate can be set at the lowest possible level - no more than 1-2\% of turnover at each stage of reselling of goods (works, services) by including deals based on retail buy and sell contracts into the taxation base (Barulin, 2014). But it will lead to an unpredictable growth of prices and tariffs because there will be a cascade inclusion of the sales tax into them from the producer to the retailer, which in the end will lead to higher inflation in the country (Bloshenko et al., 2015).

Another negative feature of the sales tax introduction is a more complicated procedure of its administration, the need of meticulous control over all sales points, including with the use of cash registers in retail (Pogorletskiy and Bashkirova, 2015). Such a measure undoubtedly only increases tax administration.

In international practice the sales tax, which is a tax on consumption, is collected once when selling goods (works, services) to the end consumer. At that, trade intermediaries as a rule are exempt from the tax, if they are not end users. At that, when sticking to such rules, companies must present a special certificate of resale, "a resale certificate," when selling goods. If the certificate is not presented, the sales tax must be paid by the whole chain of resellers (Gillooly, 1993). The taxation base is the price of sold goods. The sales tax used in the USA leads to a significant increase of the tax burden both for the tax payers, who are intermediaries or who in fact include the tax in the product they create (Fig. 8). 


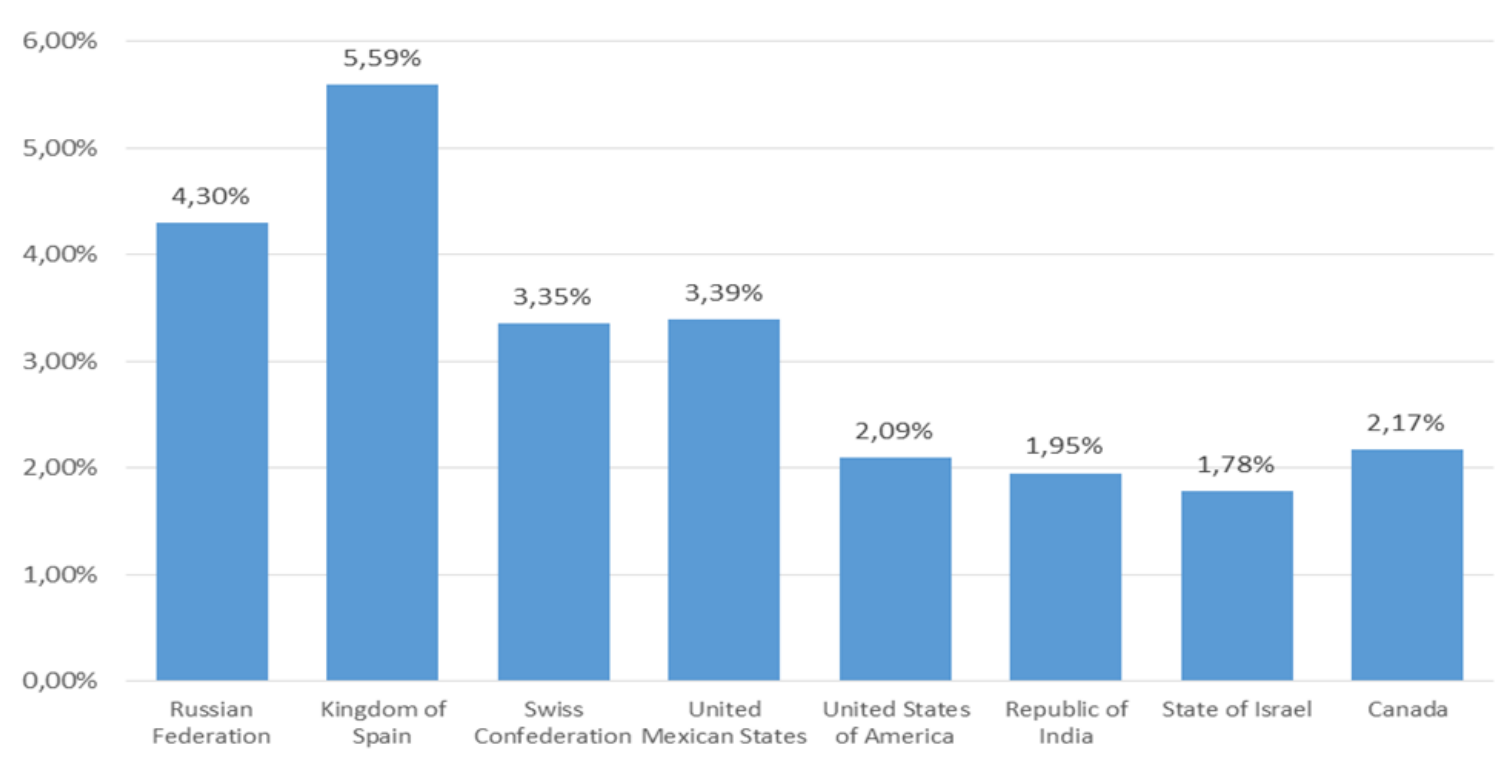

Fig. 8. Comparison of average key VAT rates and the sales tax with GDP volumes for the $1995-2015$ period, $\%$

The theory of taxation of indirect taxes says that the size of VAT and the sales tax should be identical because both taxes are aimed at end consumption of a wide range of goods, works, services (Ho, 2012). In practice, the end result is different, because there is an important difference in the order of collecting the taxes. In the USA, the sales tax is not a federal tax, because it is set by a state and locally (it is used by 45 states of the country). In their turn, the sizes of rates vary from $1.69 \%$ (Alaska) to $9.45 \%$ (Tennessee) because of tax risks connected with collectability for local budgets as well as existing competition between the states of the country in interstate and international trade (Krishnan, 2010). Besides, crossborder buy and sell operations are not taxed, if one of the parties of the deal is located outside the territory of the country (Schroyen, 2010).

As internet trade and online sales develop, the order of tax controls in the USA has been significantly strengthened via the introduction of a streamlined sales tax (SSUTA) aimed at setting a flat trade fee from potential taxation objects (in particular in the digital products area). At that, the aim of the SSUTA is voluntary participation of tax payers and their registration as tax payers.

\section{Conclusion}

The research of the effect of VAT on economies of the countries we have done revealed a number of specific drawbacks, which make the mechanism of this tax collection and payment more complicated:

1. The complicated collection order and high administration costs of value added tax. The problem covers both tax payers and tax authorities.
The difficulties encountered by all participants of the taxation process include high qualifications and working skills required not only from Russian, but also from foreign tax officers for a more efficient use of VAT and tax controls. Consequently, additional financial means should be invested in the administration process, which, in its turn, leads to high costs of tax administration

2. The volume of VAT collections for the budget. It is linked to the fact that most money is repaid to companies under illegal schemes of VAT reimbursement from the budget (Fig. 9)

Basing on the approximation method of analysis of the statistical data of VAT budget collection, we have formulated the following statement.

A gradual improvement of tax legislation has led to a firm trend of a higher VAT collection. At that the determination coefficient $\mathrm{R}^{2}=0.5919$ points to quite a high approximation of the analytical results to the factual selection of the initial data, without excluding the effect of other tax factors. We are talking about a higher volume of tax deductions, which allow taxpayers to lower their VAT taxation basis. At that during the 20102014 taxation periods the size of VAT tax deductions presented by the taxpayers increases each year.

Thus, in 2013 the sum of tax deductions amounted to $85.51 \%$ of the estimated amount of the tax, in 2014 the share decreased to $84.85 \%$. In such conditions, there is a direct danger of the sums of the taxes estimated for collection to the budget and accepted for deductions becoming equal. Formally, VAT will exist, but no funds will come to the budget from it, consequently, the tax will not perform its key function, the fiscal one. 


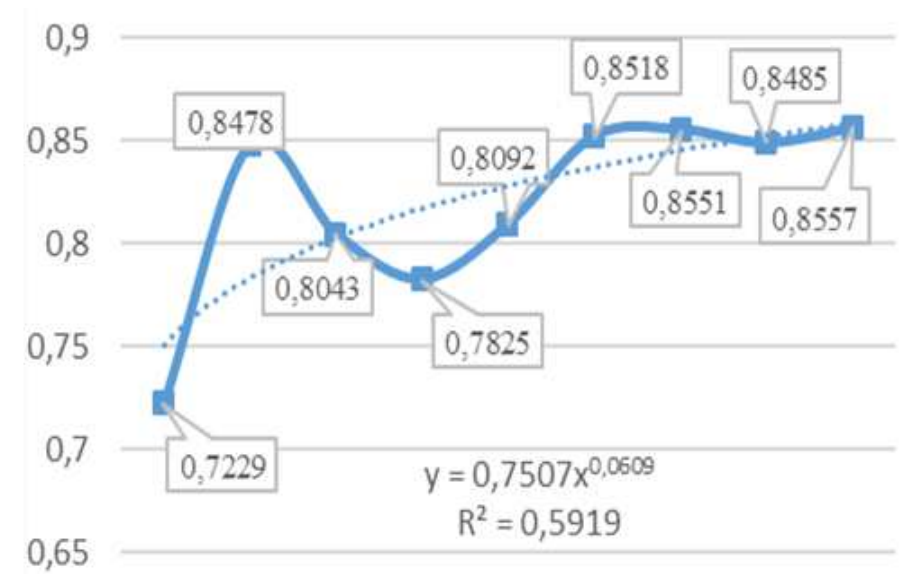

200720082009201020112012201320142015

Fig. 9. The dynamics of VAT collection into the Russian budget

Exposure of illegal VAT reimbursement is a priority task for cameral departments of the Federal Tax Service of Russia. At that, the order of tax controls has been significantly widened since 2015 . In particular, when a tax declaration is only submitted in an electronic form, tax payers must reflect the data of invoices which were both issued when selling goods (works, services) and received from their counteragents.

Thus, a higher budget efficiency of VAT collection does not so much depend on the level of rates set by law and the widening of the taxation object, as on the methods used to calculate added value. At the current stage, calculation of VAT liabilities is done with the help of an imputation system, where the definition of added value as a taxation object is not necessary. Consequently, it is important that approaches be used whereupon definition of the taxation base will be done basing on the very economic nature of added value. But the introduction of the new mechanism of added value definition and taxation is challenging in modern conditions - if costs of introduction of such an approach increase, the low investment attractiveness of doing business in the country will become even lower.

Value added tax is imperfect no more and no less than other taxes, which should not lead to a conclusion that it should be cancelled, but to improvement of the taxation system on the whole. The complicated order of VAT collection is not connected with the nature of its origin, but with the quality of administration in the taxation system. In this situation, a prosaic replacement of one tax by another looks an inefficient means of solving the current problems in the economy. Proponents of value added tax cancellation, in our view, do not take into consideration the problems and difficulties, which may arise, if it is replaced with a sales tax (Tait, 1988). We are talking about difficulties of tax administration and budget losses for the state.
Value added tax has a running system and mechanism of collection and payment and accounts for a significant share of budget revenue, but it must be improved, while its cancellation (or its replacement with a sales tax) is unwise.

At the same time VAT administration is one of the most pressing problems of tax authorities (Maisto, 2008). But it is not inherent only in Russia - other countries also encounter such difficulties. For instance, in Bulgaria, tax payers were ordered to use special banking accounts for payments of this tax to thwart illegal VAT redemption.

Another problem is linked with the need of replenishment of regional and especially local budget shortfalls, which grow from year to year. In our opinion, we should split the problems of VAT administration and strengthening financial basis of regional and local budgets and solve each problem separately.

We should note that the problem of growing VAT arrears, as our analysis shows, is also of significance. Arrears is a kind of a resulting figure of the quality of taxes and their operation in given conditions and depend on economic conditions in the state, because the effect of the economy on taxes is much stronger than their opposite effect. This is why we can see salvation of the arrears problem in an economy, which develops normally, in the possibility and wish of the tax payers to pay taxes in an honest manner in full and timely.

In its turn, economic growth depends a lot both on the taxation level, on a lower tax burden and on the creation of such a taxation model, which would ensure economic expediency, fairness and efficient administration of the taxation system.

In particular, at the current key Russian VAT rate of $18 \%$ we can assume the following concept of its cutting by taking empiric data as the basis (Table 3 ). 


\begin{tabular}{llllll}
\multicolumn{2}{l}{ Table 3. Possibilities to cut they key VAT rate in Russia } \\
\hline \multicolumn{7}{l}{$\begin{array}{l}\text { VAT arrears } \\
\text { to budget } \\
\text { (thousand roubles) }\end{array}$} & $\begin{array}{l}\text { Arrears that } \\
\text { are being settled } \\
\text { with tax payers } \\
\text { (thousand roubles) }\end{array}$ & $\begin{array}{l}\text { VAT, which was } \\
\text { in fact collected } \\
\text { for the budget } \\
\text { (thousand roubles) }\end{array}$ & $\begin{array}{l}\text { Estimated VAT } \\
\text { rate, which takes } \\
\text { fixed arrears } \\
\text { into account (\%) }\end{array}$ & $\begin{array}{l}\text { Estimated VAT } \\
\text { rate, which takes } \\
\text { arrears to budget into } \\
\text { consideration (\%) }\end{array}$ \\
\hline 2006 & 354318712 & 8527406 & 924195864 & 17.84 & 13.01 \\
2007 & 249627527 & 5914505 & 1390389912 & 17.92 & 15.26 \\
2008 & 242866793 & 9897692 & 998387698 & 17.82 & 14.48 \\
2009 & 327122082 & 182671741 & 1176607599 & 15.58 & 14.57 \\
2010 & 313238698 & 197223925 & 1328749351 & 15.67 & 15.33 \\
2011 & 304991932 & 172764160 & 1753240511 & 16.39 & 15.39 \\
2012 & 319689556 & 174902568 & 1886135362 & 16.47 & 15.40 \\
2013 & 333518737 & 172689195 & 1868209202 & 16.48 & 15.61 \\
2014 & 368006075 & 182282296 & 2181419960 & 16.61 & 16.73 \\
2015 & 375535825 & 185134352 & 2448348374 & & \\
\hline
\end{tabular}

Taking the figure of the factual volume of VAT collection for the budget for the period of 2006-2015 as the basis, if the current preferential conditions for the tax are kept, the key tax rate can be cut using the following formula:

$$
V A T_{\text {rate }}=0.18 \times V A T_{\text {fact }} \times 100 \% /\left(V A T_{\text {fact }+} V A T_{\text {debt }}\right)
$$

Where:

$$
\begin{aligned}
V A T_{\text {fact }}= & \text { The sum of VAT, which in fact was collected } \\
& \text { for the budget in the corresponding period } \\
V A T_{\text {debt }}= & \text { The sum of tax arrears, which was fixed and } \\
& \text { paid by the taxpayers in fact }
\end{aligned}
$$

While applying Formula 3 to Table 3 we will demonstrate the possibility of the key VAT rate cut for the taxation period of the year of 2015:

a) when registering repaid debt of tax payers to the budget, the estimated VAT rate is $16.73 \%=0.18 \times$ $2448348374 \times 100 \% /(2448348374+185134352)$

b) when tax arrears to the budget are repaid in full, the estimated VAT rate is $15.61 \%=0.18 \times$ $2448348374 \times 100 \% /(2448348374+375535825)$

Another problem of falling tax control efficiency is a negative arbitration practice, where courts side with the taxpayer and decree in their favor, demonstrates the imperfection of tax legislation anew. Special concern is caused by the absence of positive changes in tax legislation. Moreover, it seems that the position of lawyers is becoming even more intolerant and unrealistic.

The tax authorities now pay great attention to solving this problem, in particular, they accumulate arbitrary practice in favour of the taxation bodies with the help of a meticulous selection of proofs of tax legislation violation by tax payers. But collecting additional documents require a lot of time. An important direction in removing many problems, as well as in improving tax administration in the sphere of taxation, in particular, in indirect taxation, lies in the improvement of cooperation between the tax authorities and other state services.

Thus, we may make a conclusion that any tax is as good as its collectability. In other words, the efficiency of any tax is defined by the simplicity of its administration. Many countries are making significant efforts to introduce new economically unjustified tax liabilities and take little heed about higher collectability of VAT and the use of modern automated systems and methods of checks. This is why the main effort should be undertaken to improve legislation and the procedures, which require a lot of administrative expenses, but ensure little growth of payments to the budget.

Measures aimed at increasing the tax payers' income should be undertaken to solve the problem of taxation of added value. One of the directions of the policy to increase incomes in the taxation system is optimization of the tax privileges and exemption system as well as the removal of possibilities for tax evasion. Value added tax is one of the most common taxes ensuring a significant share of budget revenue. Despite quite an extensive practical experience of collecting this tax the mechanism of calculation is subject for studies and constant discussions both from a theoretical and methodological and practical points of view.

\section{Acknowledgement}

The authors are grateful to an anonymous reviewer for his useful contribution in adding value to this article. But the authors are responsible for comments and analysis of the whole text of the article.

\section{Author's Contributions}

Ravil Gabdullaevich Akhmadeev, Mikhail Evgenievich Kosov and Olga Alekseevna Bykanova: The conceptual plan of the research, collection and analysis of the results, the writing of the article.

Author Svetlana Viktorovna Frumina: The analysis of conclusions and results of the research, participation in writing the article. 
Author Marina Vladimirovna Melnichuk: Critical realization of the concept of the article, participation in writing the article.

\section{Ethics}

Authors should address any ethical issues that may arise after the publication of this manuscript.

\section{References}

Adams, T.S., 1918. The Taxation of Business. Proceedings of the Annual Conference on Taxation under the Auspices of the National Tax Association, Nov. 13-16, National Tax Association, pp: 185-194.

Akhmadeev, R.G. and M.E. Kosov, 2015. Taxes on final consumption in OECD countries and the Russian Federation. Finance Credit, 44: 51-62.

Akhmadeev, R.G., M.E. Kosov, O.A. Bykanova, E.M. Korotkova and O.I. Mamrukova et al., 2016. Assessment of the tax base of the consolidated group of taxpayers in Russia using the method of polynomial interpolation. Ind. J. Sci. Technol., 9: 0974-6846. DOI: 10.17485/ijst/2016/v9i12/89533

Amand, C., 2007. VAT grouping, FCE bank and force of attraction. Int. VAT Monitor., 18: 237-249.

Barulin, S.V., 2014. Problems and solutions of valueadded taxation. Sci. Society, 3: 32-38.

Black, J., 2012. A Dictionary of Economics. 1st Edn., Oxford University Press, Oxford, ISBN-10: 0199696322, pp: 464.

Bloshenko, T., V.V. Ponkratov and A.S. Pozdnyaev, 2015. Impact of financial derivatives on calculation and payment of mineral extraction tax. Mediterranean J. Social Sci., 6: 320-326. DOI: $10.5901 / \mathrm{mjss} .2015 . v 6 n 5 s 4 p 320$

Chernik, D.G., 2015. Taxes as a factor of financial stability. Group Compan. MCFER Consult. Chamber Tax Advisers Russia, 190: 174-183.

Couzin, R., 2014. Policy forum: The end of transfer pricing. Canad. Tax J., 61: 159-178.

Crum, R.P., 1982. Value-added taxation: The roots run deep into colonial and early America. Account. Historians J., 9: 25-42.
Gillooly, M., 1993. The Law Relating to Corporate Groups. 1st Edn., Federation Press, Sydney, ISBN-10: 1862871108, pp: 252.

Ho, V., 2012. Theories of corporate groups: Corporate identity reconceived. Seton Hall Law Rev., 42: 878-951. DOI: 10.2139/ssrn.1915745

Kosov, M.E. and R.G. Akhmadeev, 2015. Foreign experience of tax stimulation of innovative activity. Proceedings of the Conference on East West Association for Advanced Studies and Higher Education GmbH (HEG' 15), Vienna, pp: 67-73.

Krishnan, S., 2010. Transfer pricing regulations-a comparative study on the confluence and conflict between India, the OECD and other countries. AsiaPacific Tax Bullet., 16: 24-35.

Law, J. and G. Owen, 2010. A Dictionary of Accounting. 1st Edn., Oxford University Press, Oxford, ISBN-10: 0199563055, pp: 439.

Law, J., 2009. A Dictionary of Business and Management. 5th Edn., Oxford University Press, Oxford, ISBN-10: 0191036722, pp: 608.

Maisto, G., 2008. International and EC Tax Aspects of Groups and Companies. 1st Edn., IBFD, Amsterdam, ISBN-10: 9087220286 , pp: 564.

Moles, P., 1997. The Handbook of International Financial Terms. 1st Edn., Oxford University Press, Oxford, ISBN-10: 0198288859, pp: 605.

Pogorletskiy, A.I. and N.N. Bashkirova, 2015. The dynamics of tax system and tax administration development in the Russian Federation. J. Tax Reform, 1: 4-24. DOI: 10.15826/jtr.2015.1.1267

Schenk, A. and O. Oldman, 2007. Value Added Tax: A Comparative Approach. Cambridge University Press, ISBN-10: 1139458264.

Schroyen, F., 2010. Operational expressions for the marginal cost of indirect taxation when merit arguments matter. Int. Tax Public Finance, 17: 43-51. DOI: $10.1007 / \mathrm{s} 10797-008-9098-4$

Tait, A.A., 1988. Value Added Tax: International Practice and Problems. International Monetary Fund, Washington, ISBN-10: 1455265837, pp: 467. 